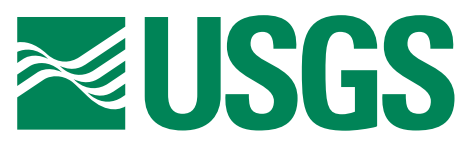

science for a changing world

\title{
Landslide Hazards at La Conchita, California
}

\author{
By Randall W. Jibson
}

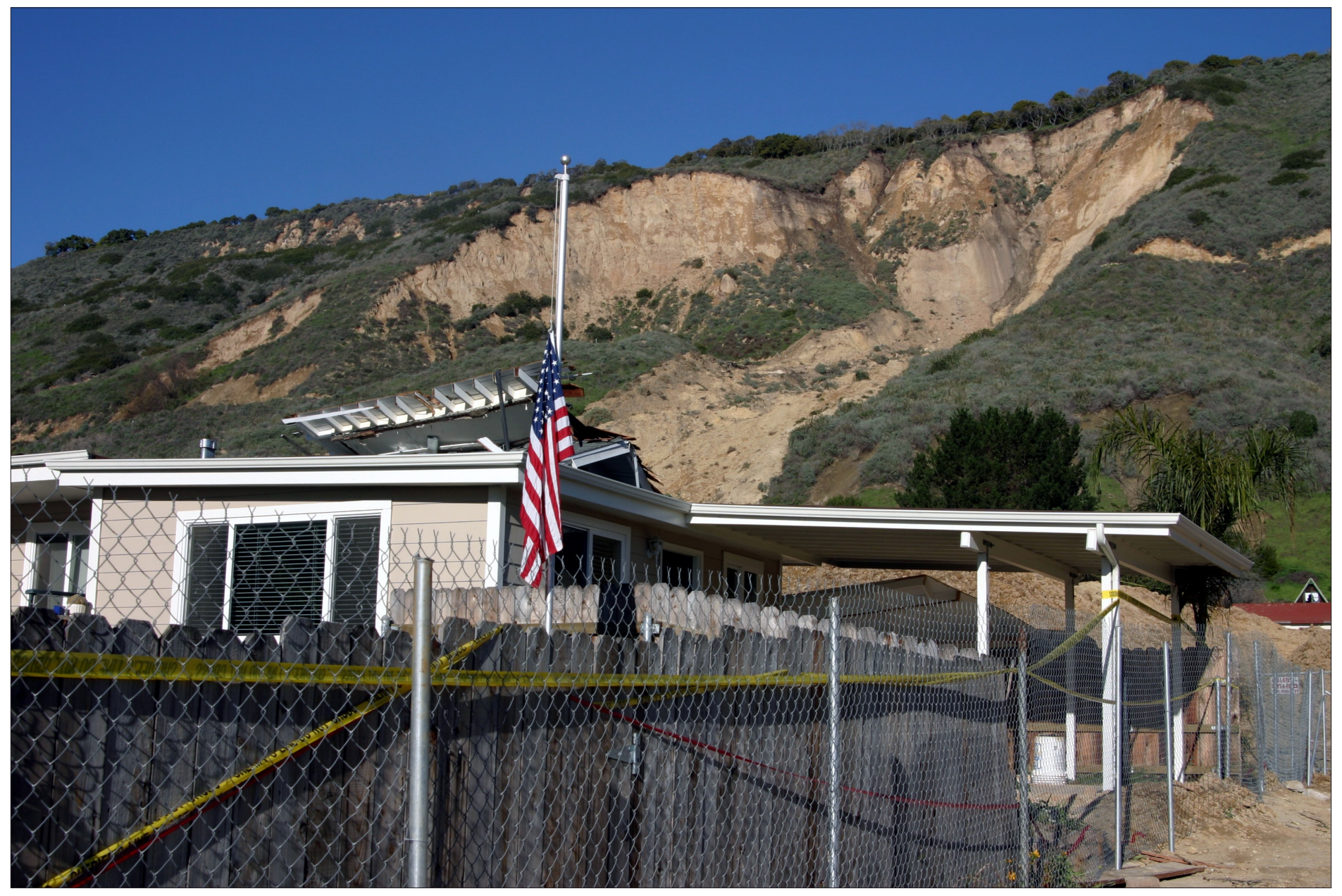

Open-File Report 2005-1067

U.S. Department of the Interior

U.S. Geological Survey 
This report has not been reviewed for stratigraphic nomenclature.

Any use of trade, firm, or product names is for descriptive purposes only and does not imply endorsement by the U.S. Government. 


\section{Introduction}

On January 10, 2005, a landslide struck the community of La Conchita in Ventura County, California, destroying or seriously damaging 36 houses and killing 10 people. This was not the first destructive landslide to damage this community, nor is it likely to be the last. On January 14, 2005, at the invitation of the California Geological Survey, I visited La Conchita with James O'Tousa, contract geologist for Ventura County, and Pamela Irvine, Janis Hernandez, and Terry Jones, all from the California Geological Survey. This report describes my field observations and provides a description of the La Conchita area and its landslide history, a comparison of the 1995 and 2005 landslides, and a discussion of continuing landslide hazards in the La Conchita area.

\section{Setting of La Conchita}

La Conchita is located on the southern California coastline midway between Ventura and Santa Barbara (fig. 1). The 11-ha (28-acre) community was first established in 1924 when subdivision created about 200 lots that mostly contain singlefamily residences. La Conchita lies on a narrow coastal strip about $250 \mathrm{~m}(800 \mathrm{ft})$ wide between the shoreline and a $180-\mathrm{m}$ (600-ft) high bluff having a slope of about $35^{\circ}$; above the top of the bluff is a gently rising terrace surface covered by avocado and citrus orchards (fig. 2).

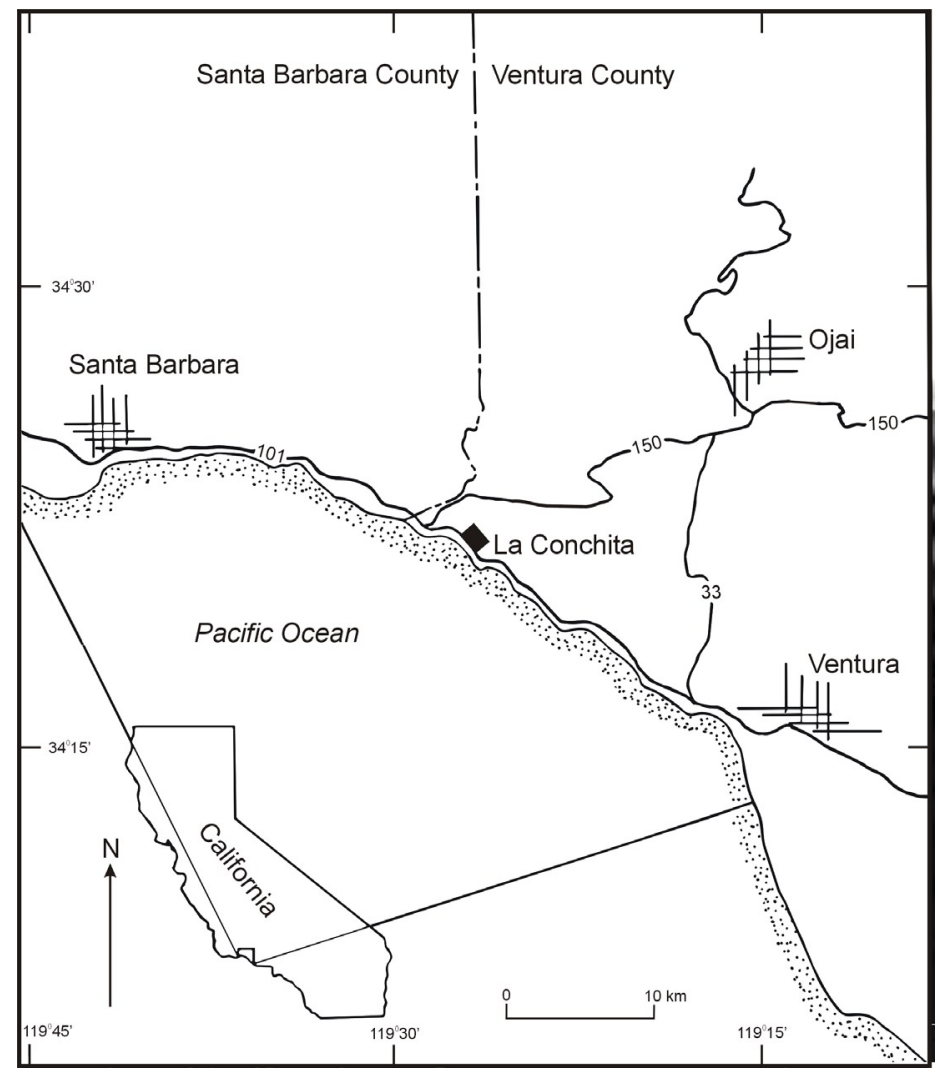

Figure 1. Location map showing the La Conchita area (after O’Tousa, 1995).

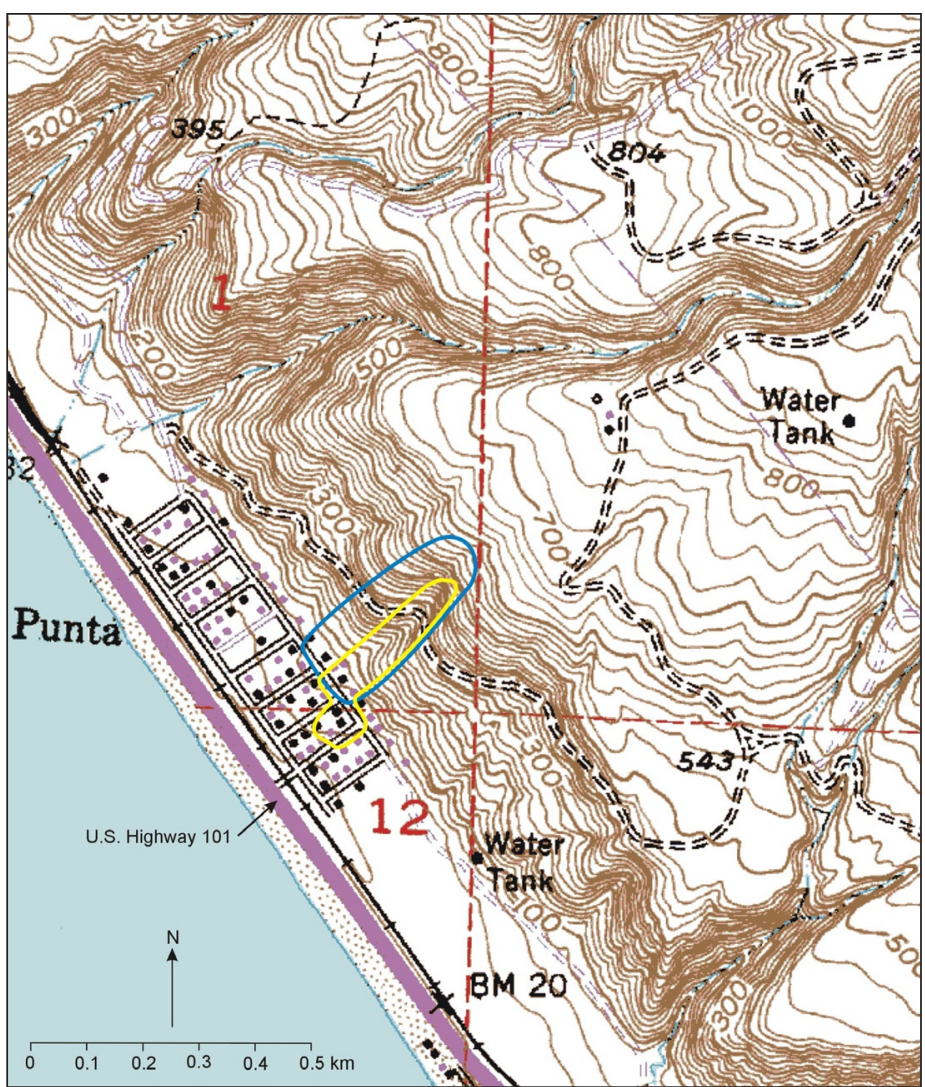

Figure 2. Topographic map showing the La Conchita area. Approximate outlines of 1995 (blue) and 2005 (yellow) landslides are shown. Base from U.S. Geological Survey Pitas Point 7.5' quadrangle, contour interval $20 \mathrm{ft}(6.1 \mathrm{~m})$, datum mean sea level; map center is at UTM $11275256 \mathrm{E} 3805431 \mathrm{~N}$.

The bluff above La Conchita consists of poorly indurated marine sediment of the Monterey and Pico Formations. The upper part of the slope consists of interlayered siliceous shale, siltstone, and sandstone of the Middle to Upper Miocene Monterey Formation. The lower part of the slope is siltstone, sandstone, and mudstone of the Pliocene Pico Formation (O'Tousa, 1995). Rock of both formations is very weakly cemented and has been regionally associated with extensive landslide activity (Morton, 1971; Harp and Jibson, 1995, 1996; Parise and Jibson, 2000). The two formations are in fault contact along the active Red Mountain Fault, which extends across the slope face.

\section{Landslide History}

The bluff above La Conchita has produced a variety of landslides over an extended period of time. Figure 3 shows LIDAR and false-color infrared images of the bluff above La Conchita and the surrounding area, and several sizes, types, and ages of landslides are visible. The arcuate bench at the top of the bluff is the head of a very large prehistoric landslide that affected the entire bluff. Several smaller, more recent slumps and earth flows also are visible, as is the 1995 slump-earth flow 
A

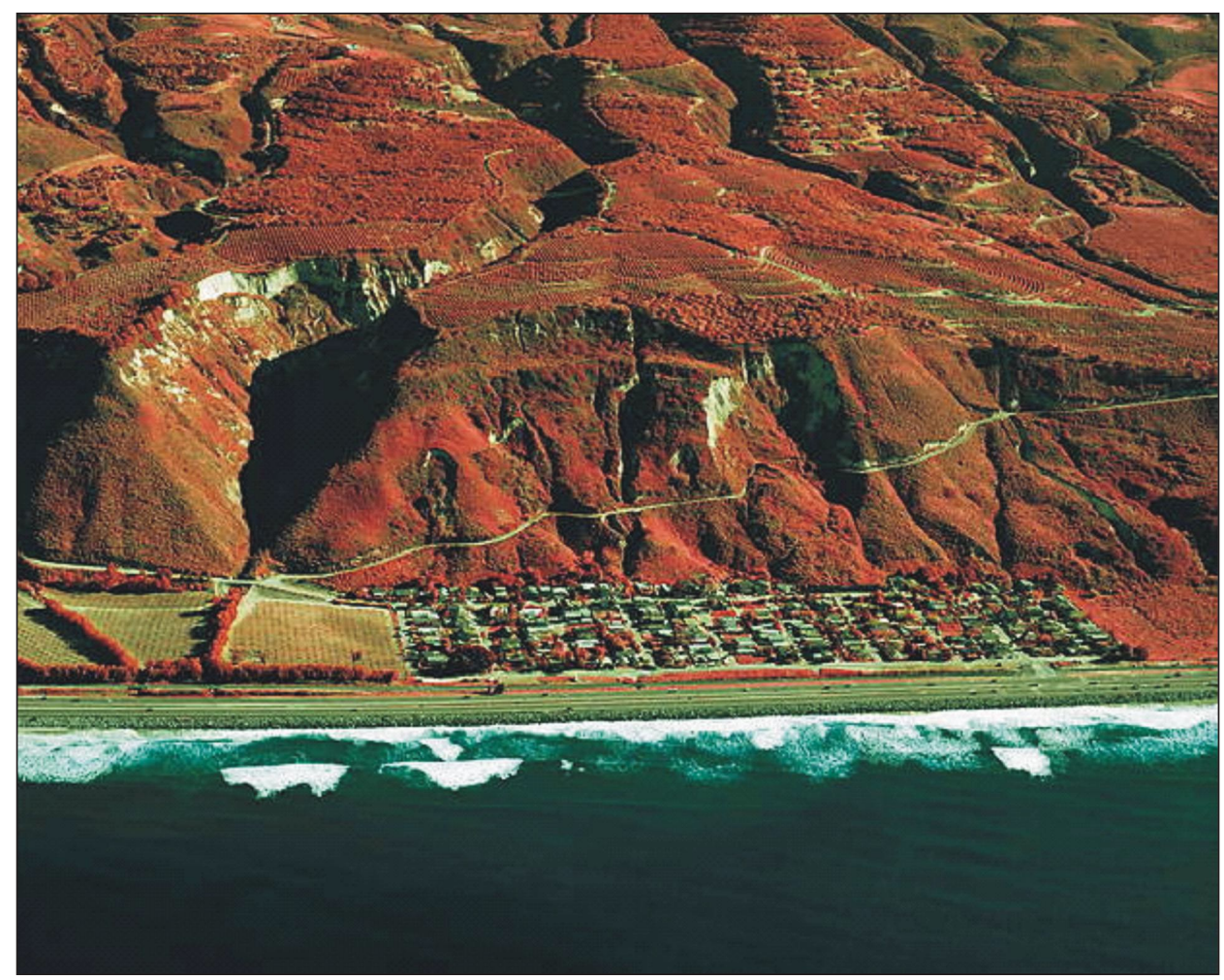

B

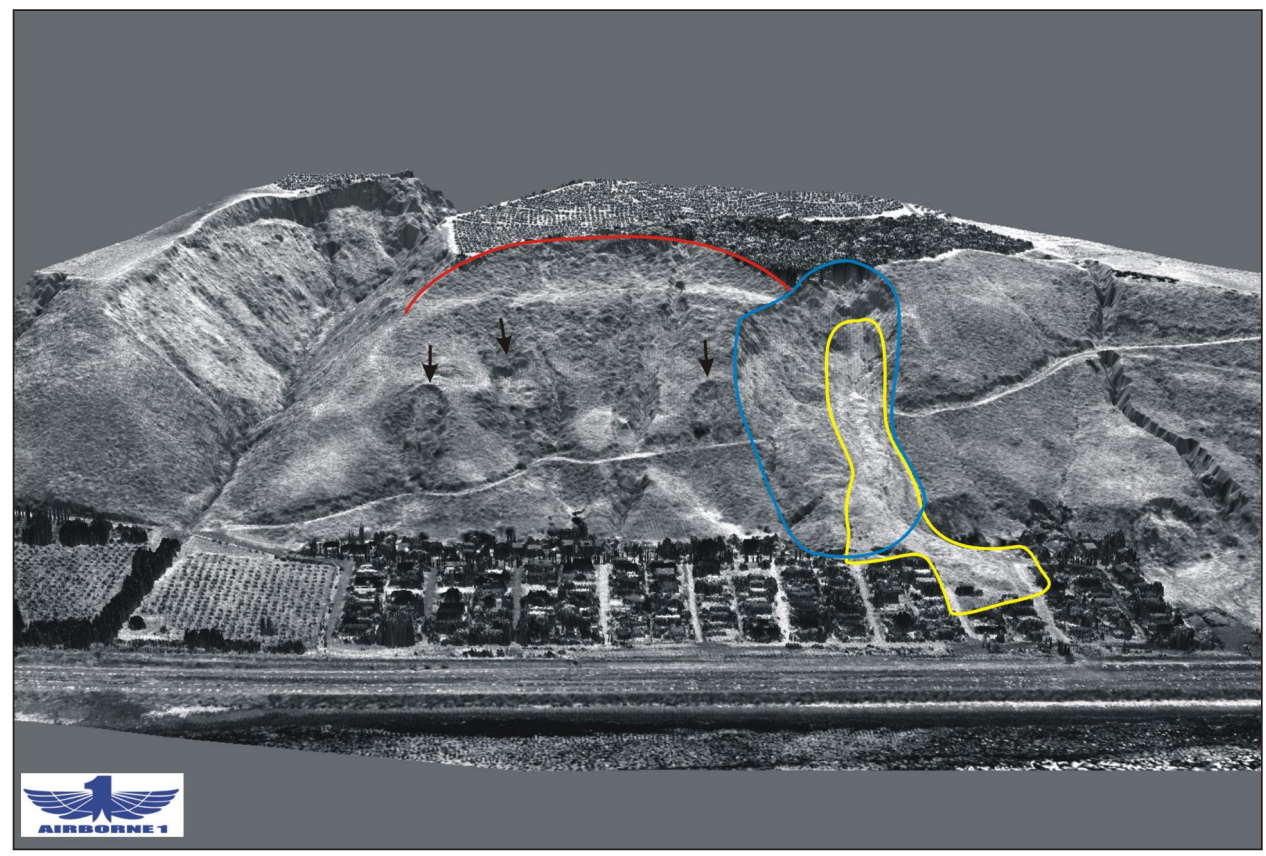

Figure 3a. Oblique false-color infrared photograph of $\mathrm{La}$ Conchita taken in 2002. The arcuate bench near the top of the bluff in the center of the photograph is the main scarp of an ancient landslide that involved the entire bluff. The 1995 landslide is visible in the right center of the photograph. Other landslides of various ages and sizes are visible on the slopes. Photograph courtesy of Robert Larson, GeoArchives Photography.

Figure 3b. Oblique LIDAR image of La Conchita after the 2005 landslide. Outline of 1995 (blue) and 2005 (yellow) landslides shown; arrows show examples of other landslides in the area; red line outlines main scarp of an ancient landslide that involved the entire bluff. The deep canyon on the left produced major debris flows in both 1995 and 2005. Image courtesy of Airborne 1 Corporation, El Segundo, Calif. 
(terminology after Varnes, 1978). Similar combinations of large ancient landslides and smaller, recently active landslides also are present in areas southwest of the 1995 and 2005 landslides. In addition, large and small ravines that incise the bluff have produced debris flows recently and in the past.

Historical accounts dating back to 1865 have reported landslides in the area around La Conchita as being a regular occurrence (Hemphill, 2001). The Southern Pacific rail line that extends along the coastal strip was inundated by landslide debris in 1889 and again in 1909, when a train also was buried (Hemphill, 2001). Since that time, landslides frequently have inundated roads, railroads, cultivated land, and more recently, the La Conchita community (O’Tousa, 1995).

\section{La Conchita Landslide}

The following summary of the 1995 La Conchita landslide is extracted from O'Tousa (1995) and Anderson (Robert Anderson, RJR Engineering, 2005, personal commun.). On March 4, 1995 at 2:03 p.m. PST, the La Conchita landslide failed and moved tens of meters in only a few minutes. The landslide, a complex slump-earth flow, destroyed or severely damaged nine houses. On March 10, a subsequent debris flow from a canyon to the northwest (see canyon on left part of figs. 2 and 3) damaged five additional houses in the northwestern part of La Conchita. The main mass that failed is on the southeastern margin of the larger ancient landslide that encompasses the entire front of the bluff (see fig. 3). The 1995 slide was $120 \mathrm{~m}$ (400 ft) wide, $330 \mathrm{~m}$ (1100 $\mathrm{ft}$ ) long, and covered approximately 4 ha (10 acres). The depth was estimated at greater than $30 \mathrm{~m}(100 \mathrm{ft})$, and the volume was

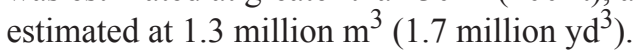

Incipient movement of the upper part of the slide was reported as early as the summer of 1994, when surface cracks were observed in the upper part of the slope (O'Tousa, 1995). Deformation continued as the rainy season began, and by December 1994, several open cracks on the hillside were channeling surface runoff into the subsurface. Several smaller landslides occurred between the summer of 1994 and March 1995, when the large slide occurred.

The 1995 landslide apparently occurred as a result of an extraordinarily wet year. Mean seasonal rainfall at Ojai $(20 \mathrm{~km}$ [12 mi] northeast of La Conchita) from October 1 through March 3 (the day before the landslide occurred) is $390 \mathrm{~mm}$ (15.37 in) (National Oceanic and Atmospheric Administration, 1994a, 1995a). In 1994-95, about twice as much rain - 761 mm (29.96 in) - fell during that period (National Oceanic and Atmospheric Administration, 1994b, 1995b). Figure 4 shows the rainfall

\section{Ojai Daily Rainfall}

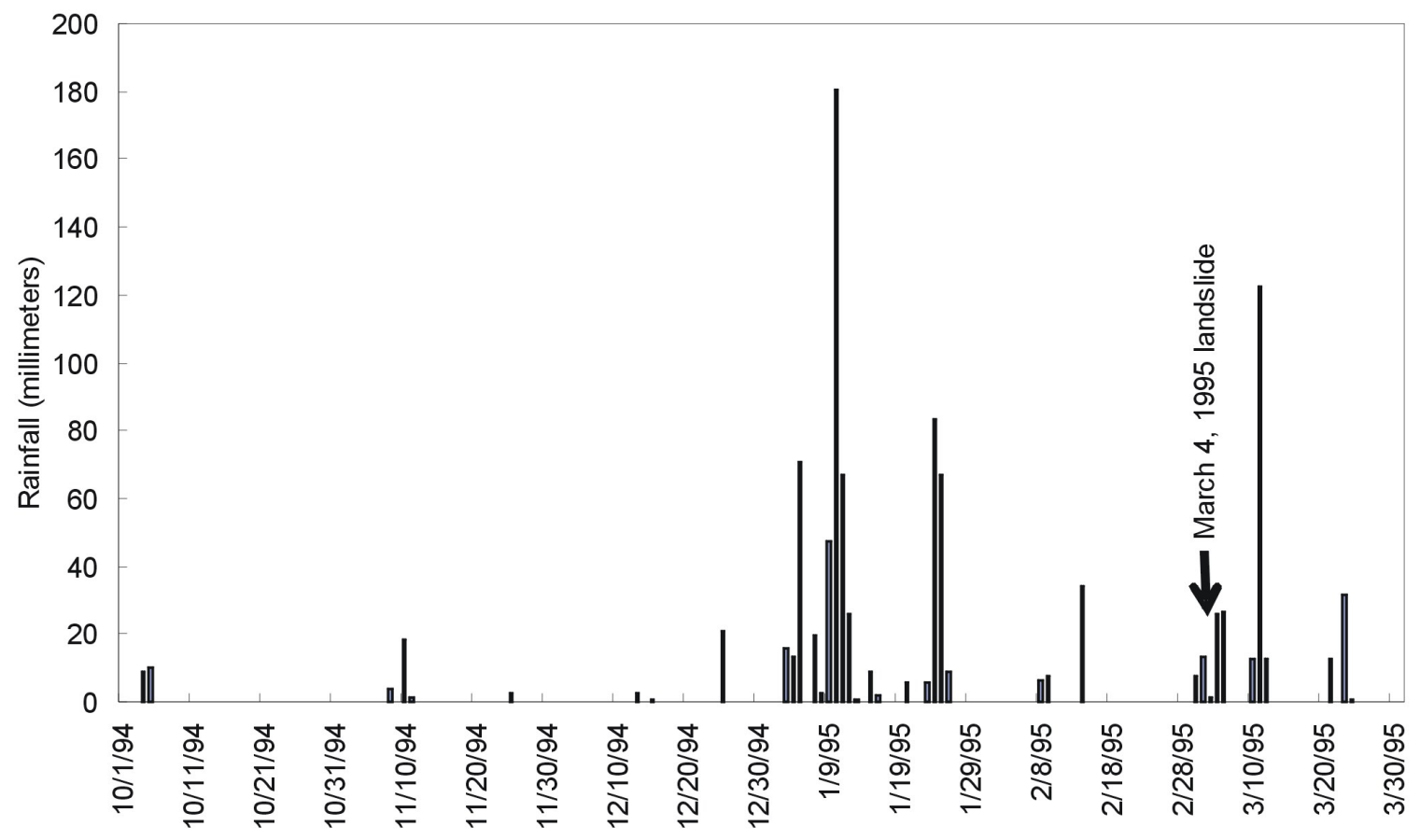

Figure 4. Daily rainfall at Ojai (20 km [12 mi] northeast of La Conchita) from October 1, 1994, through March 31, 1995 (data from National Oceanic and Atmospheric Administration, 1994b, 1995b). The 1995 landslide occurred more than 1 month after the heaviest rainfall of the season. 
distribution during the 1994-1995 rainy season. Most of the excess rain fell in January, which had $623 \mathrm{~mm}$ (24.53 in) as compared to a normal rainfall of $108 \mathrm{~mm}$ (4.26 in). February 1995 produced only about one-third of the normal rainfall, but a modest storm on March 2-3 produced $21 \mathrm{~mm}$ (0.81 in) of rain. The La Conchita landslide then occurred on March 4.

As discussed above, the 1995 landslide was relatively deep and primarily moved as a coherent slump-earth flow. This mode of movement suggests that the landslide formed as a result of rising ground-water levels in response to deep infiltration of antecedent seasonal rainfall. In particular, the extraordinary rainfall of January 1995 probably was the principal contributing factor to the elevated ground-water levels and, hence the landslide movement. The storm of March 2-3 also may have played a role in triggering initial movement of the hillside, which already was approaching instability due to longer-term seasonal rises in ground-water levels. Eyewitness accounts indicate, however, that similar to 2005, dust was in the air and much of the deposit included relatively dry material. Eyewitnesses also reported seeing material failing from the main scarp and lateral margins of the landslide as a result of removal of lateral support.

\section{La Conchita Landslide}

The 2005 La Conchita landslide occurred at about 12:30 p.m. on January 10. Little or no newly failed material was involved in the landslide; rather, it consisted of a remobilization of the southeastern portion of the 1995 landslide deposit, involving about 200,000 $\mathrm{m}^{3}\left(250,000 \mathrm{yd}^{3}\right)$ (James O'Tousa, RJR Engineering, personal commun., 2005). The landslide area was approximately $350 \mathrm{~m}$ (1,150 ft) long and 80-100 m (260-330 ft) wide. The landslide entered the La Conchita neighborhood destroying 13 houses and severely damaging 23 others (figs. 5 and 6). There were 10 confirmed fatalities.

Earlier that morning, debris flows from canyons northwest of La Conchita reached Highway 101. Law enforcement officers and media representatives were in the area, which facilitated capturing the moving landslide on video. The KCAL-TV video indicates that the landslide material mobilized simultaneously and nearly instantaneously into a highly fluid, rapidly moving debris flow. I estimate from viewing the video that high on the slope, the landslide was moving perhaps $10 \mathrm{~m} / \mathrm{s}(30 \mathrm{ft} / \mathrm{s})$. The developed part of the slope where the houses were impacted has a flatter slope, and so the flow probably slowed to no more than $5 \mathrm{~m} / \mathrm{s}$ $(15 \mathrm{ft} / \mathrm{s})$ in the neighborhood. This slower rate also is suggested by eyewitnesses who stated that some residents were able to outrun the advancing flow, which would not have been possible at the higher upslope velocity.

The 2005 landslide occurred at the end of a 15-day period that produced record and near-record amounts of rainfall in many areas of southern California. At Ventura (20 km [12 mi] southeast of La Conchita) seasonal antecedent rainfall from October 1, 2004 through January 10, 2005 totaled $493 \mathrm{~mm}$ (19.4 in) as compared to the mean value of $122 \mathrm{~mm}$ (4.8 in). From December 27, 2004 through January 10, 2005, Ventura received $378 \mathrm{~mm}$ (14.9 in) of rainfall, only slightly less than its mean annual total of $390 \mathrm{~mm}$ (15.4 in) (Wofford, 2005; National Oceanic and Atmospheric Administration, 1994a, 1995a). Although rainfall intensities were not extreme, moderate- to high-intensity rainfall persisted for more than 2 weeks, and the landslide occurred at the culmination of this 15-day high-rainfall period (fig. 7).

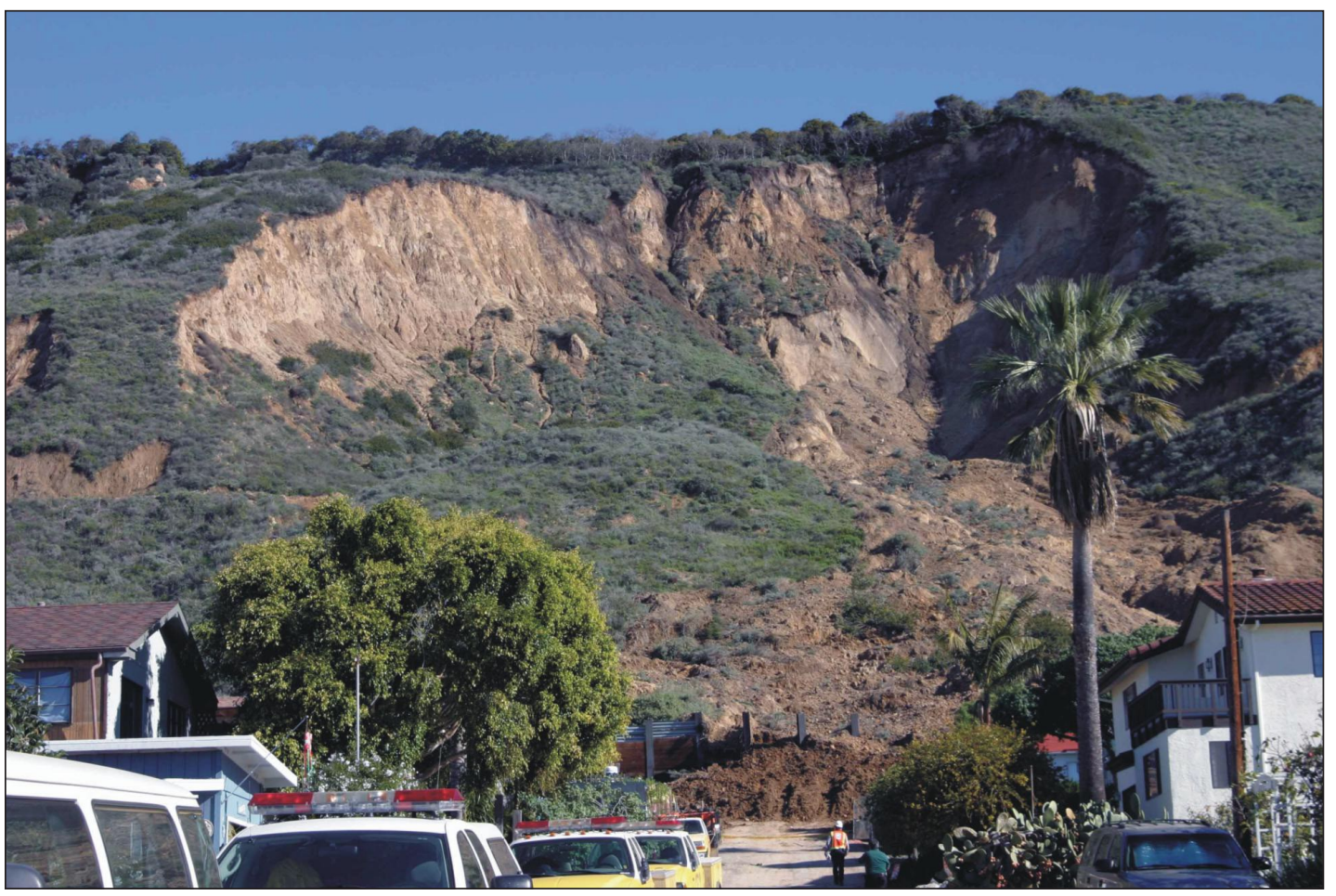

Figure 5. View of the La Conchita landslide taken January 14, 2005. The lightcolored, exposed rock in the upper part of the photograph is the main scarp of the 1995 slide. The southeast part of the 1995 deposit (right side of photograph) remobilized in 2005. At the bottom center of photograph, a wall built after the 1995 slide is visible; the 2005 slide overtopped and tilted parts of the wall forward. 


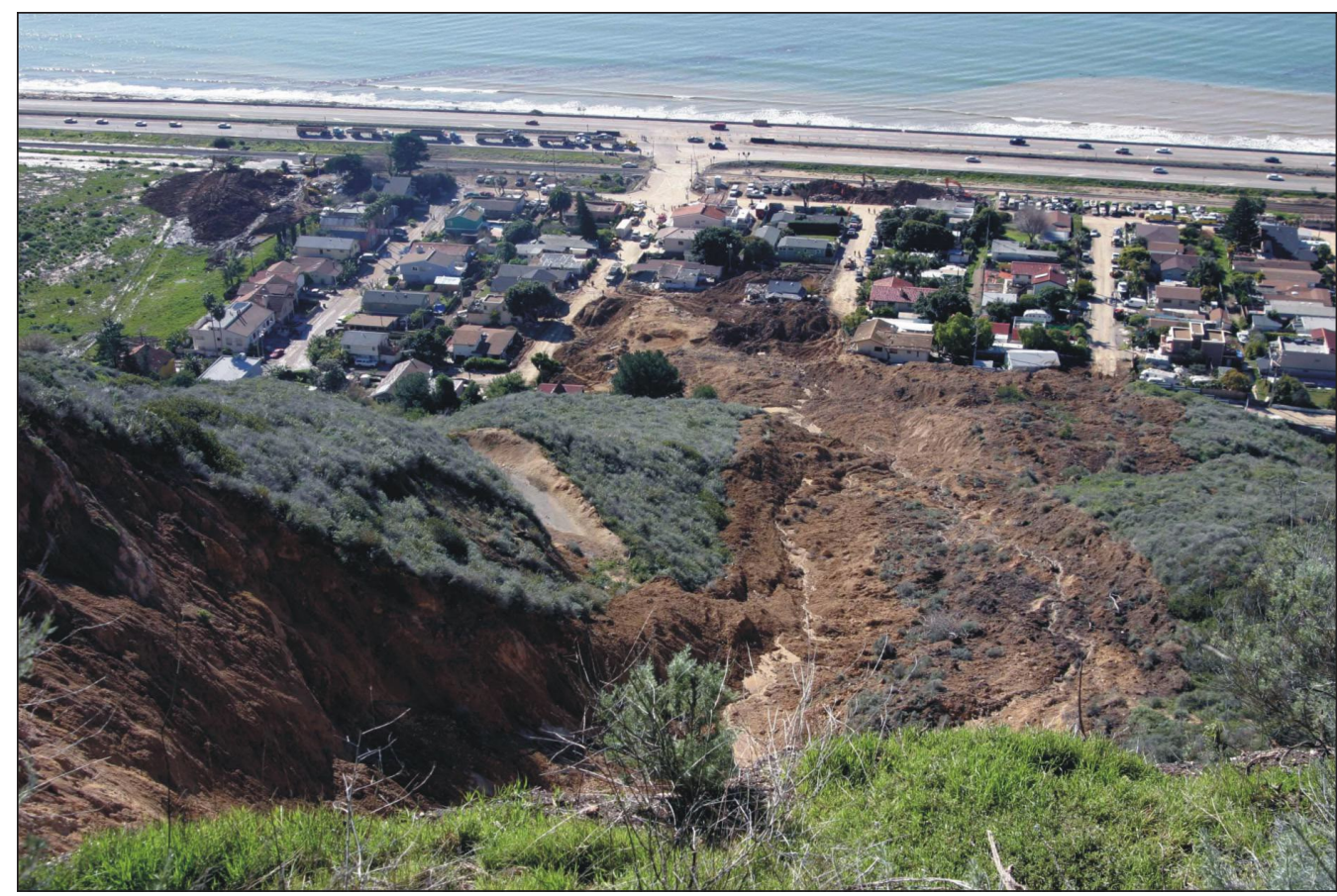

Ventura Daily Rainfall

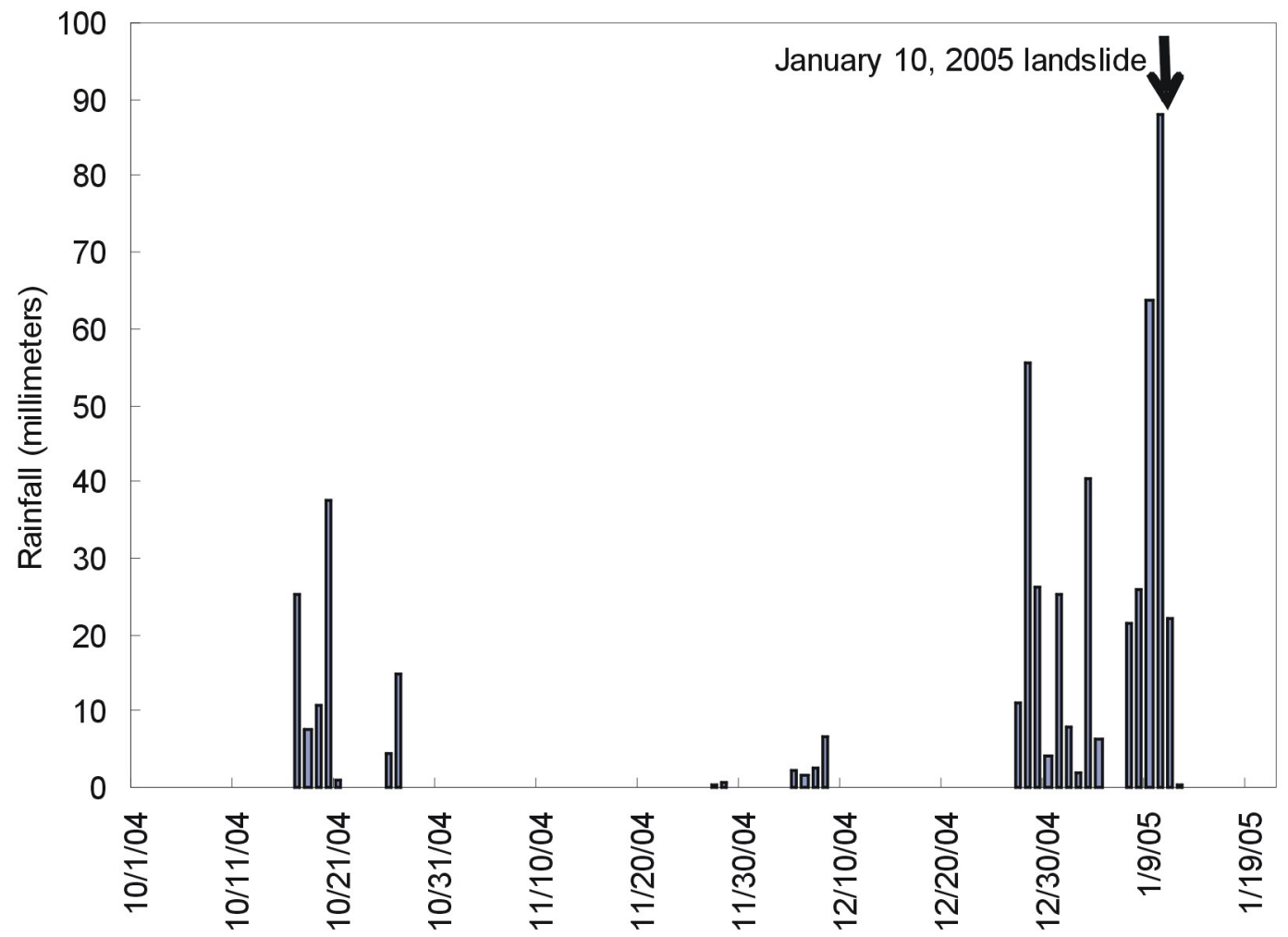

Figure 6. View from the main scarp down the length of the $2005 \mathrm{La}$ Conchita landslide. Water visible in the center of the photograph was issuing from the base of the main scarp when the photograph was taken (January 14, 2005). The 2005 landslide remobilized about 15 percent of the 1995 deposit and followed the left margin (looking downslope) of the 1995 slide. The vegetated ridge in the left part of the photograph is intact material that did not fail in 1995 or 2005; the material in the right part of the photograph is 1995 deposit that is still in place.
Figure 7. Daily rainfall at Ventura (20 km [12 mi] southeast of La Conchita) from October 1, 2004 through January 20, 2005 (data from Wofford, 2005). The 2005 landslide occurred at the culmination of the heaviest rainfall of the season. 
Inspection of the site within a few hours of the landslide indicated that much of the deposit consisted of fairly dry material (James O’Tousa, RJR Engineering, personal commun., 2005). Also, the video shows dust in the air as the landslide flowed downslope. Thus, it appears that the landslide mobilized on a saturated layer deep in the 1995 deposit but that much of the material above this saturated zone was dry or nearly so. The video shows relatively intact vegetation being rafted on the surface of the rapidly flowing mass, which indicates that much of the landslide mass simply was being carried on the fluidized layer at depth, which presumably was much more saturated.

Such a failure scenario, involving a significant amount of dry material that fully mobilized on a saturated layer, indicates that most of the rain that fell on the surface of the 1995 deposit did not infiltrate but drained off the surface. The rising ground-water level within the 1995 deposit would thus have resulted from deeper recharge from rainfall infiltration upslope. Figure 8 shows an aerial photograph of La Conchita taken in September 2004. The lush, green vegetation visible in the southeastern (lower right in photograph) part of the 1995 deposit clearly indicates that drainage on and within the 1995 landslide deposit concentrated water in the part of the mass that failed in 2005. At the time of our visit (January 14, 2005) water was still issuing from the base of the main landslide scarp and was ponding at several locations on the 2005 deposit (fig. 9).

The 2005 landslide pushed many of the houses off their foundations and into each other at the toe of the landslide (figs. 10 and 11). A wall built after the 1995 landslide to keep minor landslide debris off the road was tilted forward and(or) overtopped in places by debris from the 2005 landslide (fig. 12). This indicates that the landslide material, although it flowed rapidly, was quite viscous and pushed structures in front of it rather than flowing around them or filling them with mud, as sometimes occurs with fully saturated debris and mud flows. This apparently resulted from a highly hazardous situation involving a two-phased landslide mechanism: (1) a saturated, highly fluid layer at depth on which the landslide mobilized that (2) carried a thick layer of drier, much more viscous material that effectively acted as a battering ram.

\section{Comparison of 1995 and 2005 Landslides}

The movement of the same landslide mass in 1995 and 2005 by two very different mechanisms, and with markedly different results, is difficult to explain. The 1995 landslide was a deep, coherent slump-earth flow that deformed plastically and moved slowly enough that people could get out of its way. The 2005 landslide was a shallower remobilization of the very same material into a rapid, highly fluid debris flow that buried 10 people. Although it is not uncommon for subsidiary debris flows to occur from the toes or scarps of existing landslides (Morton and Campbell, 1989), that is not what happened in 2005. This was a wholesale remobilization of a significant portion of the 1995 deposit. How and why the same material failed twice in 10 years by fundamentally different mechanisms certainly will be the object of future research, and it is much too complex to analyze in detail at this time. A few things, however, can be said.

The timing of the two landslides with respect to the triggering storms is of primary interest. In 1995, after a very wet January, the landslide did not move until more than a month later, during which time very little rain fell (fig. 4). The deep mode of failure in 1995 is consistent with this delay: deeper landslides commonly are triggered by deep infiltration of rainfall, which can take weeks or months to occur (for example, Morton and Campbell, 1989). The 2005 landslide occurred at the culmination of an extremely wet 2-week period (fig. 7). This also is consistent with the shallower, fluid mode of failure: shallow, rapid debris flows most commonly occur during periods of prolonged, intense rainfall with little or no lag time (Campbell, 1975; Keefer and others, 1987; Jibson, 1989).

However, this still leaves some troubling questions unanswered. Why did the landslide material not mobilize into a rapid debris flow in 1995? What about the remaining 1995 deposit? Since only about 15 percent of the 1995 deposit remobilized in 2005, could the remainder also mobilize into a rapid debris flow, or is it more likely to remobilize as a deep slump? Or will it remain metastable? Currently, we have insufficient data and understanding of the failure mechanisms of this landslide to adequately answer these questions, but it is clear that the hazard from renewed landslide movement is considerable.

\section{Continuing Hazards at La Conchita}

Of primary interest to the general public and various Governmental entities is the current state of hazard at $\mathrm{La}$ Conchita. While this preliminary report does not represent a detailed evaluation of those hazards, a few reasonable observations can be made.

1. Historical accounts and geologic evidence show that landsliding of a variety of types and scales has been occurring at and near La Conchita for many thousands of years, and on a relatively frequent basis, up until the present. There is no reason to believe this pattern of landsliding will stop.

2. Even in the absence of additional significant rainfall this year (2005), the remainder of the 1995 landslide could still remobilize, most likely as a deep slump-earth flow similar to that in 1995. This mode of movement would most likely be relatively slow (compared to 2005) but still could pose serious hazards to property and, perhaps, life.

3. If significant additional rainfall occurs, either this year or in future years, several landslide scenarios are possible:

(a) deep movement of the 1995 deposit, as described above, (b) mobilization of the 1995 (and possibly the 2005) deposit into a rapid debris flow such as occurred on January 10, 2005, (c) triggering of subsidiary landslides from parts of the 1995 and 2005 deposits or scarps, (d) triggering of slumps and (or) earth flows on adjacent hillsides, and (e) triggering of rapid debris flows from various nearby slopes, particularly in ravines. 

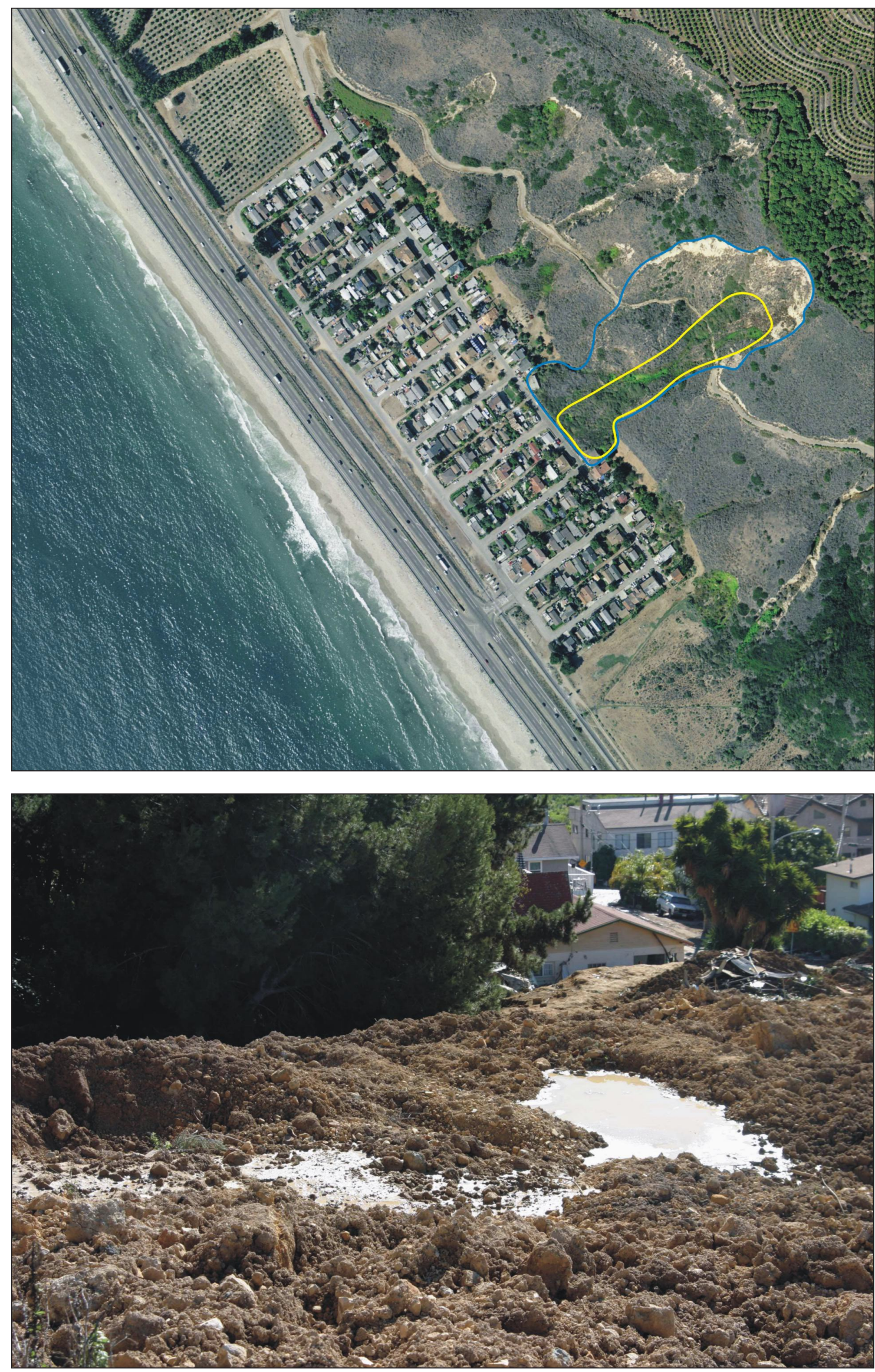

Figure 8. Othorectified airphotograph of $\mathrm{La}$ Conchita taken in September 2004. The 1995 landslide is outlined in blue; the area that remobilized in 2005 is outlined in yellow. Note the concentration of lush, green vegetation in the area that remobilized in 2005, which indicates concentration of surface and subsurface drainage into this area. Image from orthophotography provided courtesy of AirPhoto USA and County of Ventura.

Figure 9. Water was issuing from the base of the main scarp at the time of our visit (January 14, 2005). The water ponded at several locations on the 2005 deposit. 

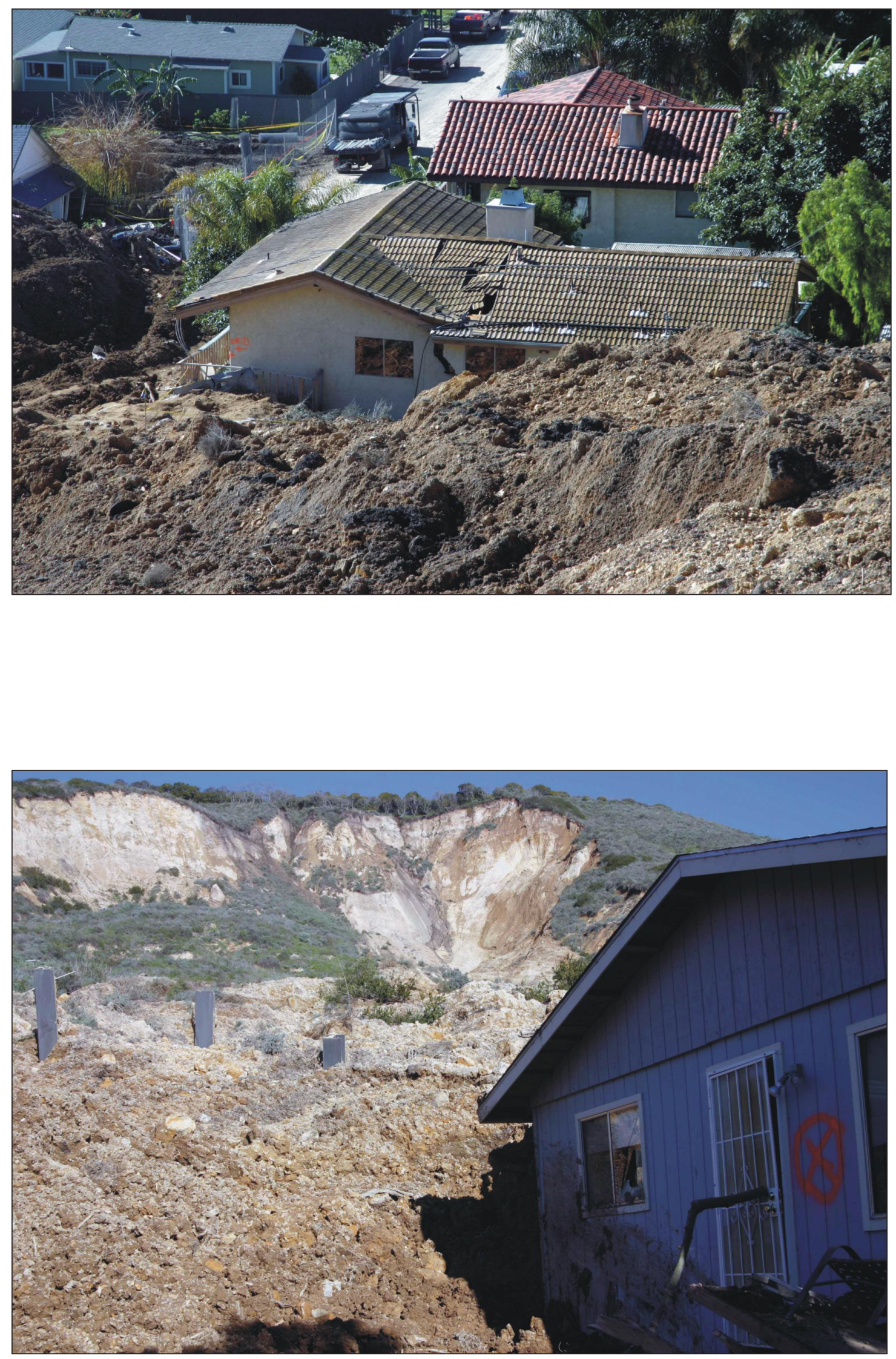

Figure 10. The 2005

landslide moved as a rapid debris flow, but it was quite viscous and pushed houses in its path rather than flowing around or through them. The left part of the house was detached from the right part and was pulled by the landslide several decimeters toward the upper left of the photograph.

Figure 11. This house was pushed about $3.5 \mathrm{~m}$ (12 ft) off its foundation toward the right in the photograph when the 2005 landslide topped a wall. The tops of the $\mathrm{H}$-beams of the wall are visible in the left part of the photograph. 


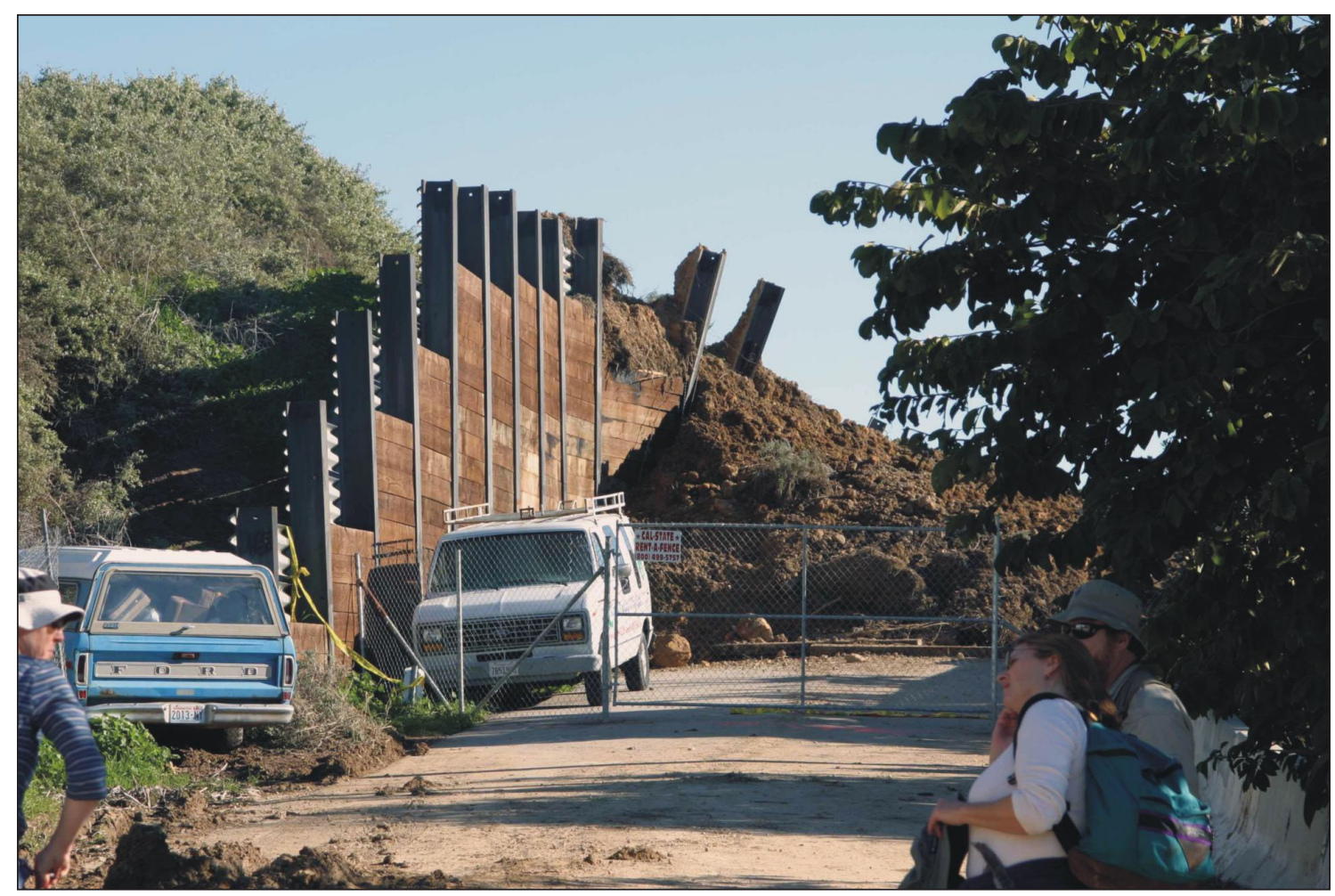

Figure 12. Steel-andtimber wall built after the 1995 landslide was overtopped and tilted forward in places by the 2005 landslide.

4. The landslide scenarios sketched above potentially could impact any part of the La Conchita community. Future landslide activity could move into the same areas that recently have been damaged or could mobilize in other directions that could damage any or all of the developed area.

\section{Conclusion}

The La Conchita area has experienced, and will likely continue to experience, a rather bewildering variety of landslide hazards. Different landslide scenarios are more or less likely to occur as a result of different specific rainfall conditions, and no part of the community can be considered safe from landslides. Unfortunately, we currently lack the understanding to accurately forecast what might happen in each possible rainfall scenario. Prudence would certainly dictate, however, that we anticipate renewed landslide activity during or after future periods of prolonged and(or) intense rainfall. Future earthquakes, of course, also could trigger landsliding in the area (Harp and Jibson, 1995, 1996).

\section{References}

Campbell, R.H., 1975, Soil slips, debris flows, and rainstorms in the Santa Monica Mountains and vicinity, southern California: U.S. Geological Survey Professional Paper 851, $51 \mathrm{p}$.

Harp, E.L., and Jibson, R.W., 1995, Inventory of landslides triggered by the 1994 Northridge, California earthquake: U.S. Geological Survey Open-File Report 95-213, 17 p.
Harp, E.L., and Jibson, R.W., 1996, Landslides triggered by the 1994 Northridge, California, earthquake: Bulletin of the Seismological Society of America, v. 86, no. 1B, p. S319S332.

Hemphill, J.J., 2001, Assessing landslide hazard over a 130-year period for La Conchita, California, in Association of Pacific Coast Geographers Annual Meeting, Santa Barbara, Calif., September 12-15 2001.

Jibson, R.W., 1989, Debris flows in southern Puerto Rico, in Schultz, A.P., and Jibson, R.W., eds., Landslide Processes in Eastern North America and Puerto Rico: Geological Society of America Special Paper 236, p. 29-55.

Keefer, D.K., Wilson, R.C., Mark, R.K., Brabb, E.E., Brown, W.M., Ellen, S.D., Harp, E.L., Wieczorek, G.F., Alger, C.S., and Zatkin, R.S., 1987, Real-time landslide warning during heavy rainfall: Science, v. 238, p. 921-925.

Morton, D.M., 1971, Seismically triggered landslides above San Fernando Valley: California Geology, v. 24, no. 4-5.

Morton, D.M., and Campbell, R.H., 1989, Cyclic landsliding at Wrightwood, southern California, in Sadler, P.M., and Morton, D.M., eds., Landslides in a semiarid environment with emphasis on the inland valleys of southern California: Inland Geological Society, Riverside, Calif., v. 2, p. 174 182.

National Oceanic and Atmospheric Administration, 1994a, Climatological data annual summary-California 1994: National Climatic Data Center, v. 98, no. 13, 60 p.

National Oceanic and Atmospheric Administration, 1994b, Climatological data-California, October-December 1994: National Climatic Data Center, v. 98, nos. 10-12. 
National Oceanic and Atmospheric Administration, 1995a, Climatological data annual summary-California 1995: National Climatic Data Center, v. 99, no. 13, 52 p.

National Oceanic and Atmospheric Administration, 1995b, Climatological data_California, January-March 1995:

National Climatic Data Center, v. 99, no. 1-3.

O’Tousa, James, 1995, La Conchita landslide, Ventura County, California: Association of Engineering Geologists AEG News, v. 38, no. 4, p. 22-24.
Parise, Mario, and Jibson, R.W., 2000, A seismic landslide susceptibility rating of geologic units based on analysis of characteristics of landslides triggered by the January 17, 1994 Northridge, California, earthquake: Engineering Geology, v. 58, p. 251-270.

Wofford, Michael, 2005, Ventura, California weather conditions: http://www.venturaweather.com/daily.htm, last visited January 28, 2005. 